\title{
Generation of a transcription map of a 1 Mbase region containing the HFE gene (6p22)
}

\author{
A ngela Totaro ${ }^{1}$, A ntonella R oetto ${ }^{2,3}$, Johanna M R ommens ${ }^{4,5}$, A nna G rifa ${ }^{1}$, \\ M assimo Carella ${ }^{1}$, L eonardo d'A gruma ${ }^{1}$, M aria A ssunta Valentino ${ }^{1}$, \\ L ucrezia D 'A mbrosio $^{1}$, M atteo Cicilano ${ }^{2}$, Clara Camaschella ${ }^{2}$, B runella Franco ${ }^{3}$ \\ and Paolo Gasparini ${ }^{1}$ \\ ${ }^{1}$ Servizio di G enetica M edica, IRCCS-O spedale 'CSS' San G iovanni Rotondo \\ ${ }^{2}$ D ipartimento di Scienze B iomediche ed O ncologia U mana, O spedale S L uigi, O rbassano (To) \\ ${ }^{3}$ Telethon Institute of G enetics and M edicine (TIGE M), San Raffaele Biomedical Science Park, M ilan, I taly \\ ${ }^{4} \mathrm{D}$ epartment of $\mathrm{G}$ enetics, R esearch Institute, The H ospital for Sick Children, Toronto \\ ${ }^{5} \mathrm{D}$ epartment of M olecular and M edical G enetics, U niversity of Toronto, Toronto, Canada
}

\begin{abstract}
A transcription map was generated of a $1 \mathrm{Mb}$ interval including the $H F E$ gene on 6p22. Thirty-seven unique cDNA fragments were characterised following their retrieval from hybridisation of immobilised YACs to primary pools of cDNAs prepared from RNA of foetal brain, human liver, foetal human liver, placenta, and $\mathrm{CaCO}_{2}$ cell line. All cDNA fragments were positioned on the physical map on the basis of presence in aligned and overlapping YACs and cosmid clones of the region. The isolated cDNAs together with established or published sequence tagged sites (STSs) and markers provided sufficient landmark density to cover approximately $90 \%$ of the $1 \mathrm{Mb}$ interval with cosmid clones. The precise localisation of two known genes (NPT1 and RING finger protein) was established. A minimum of 14 additional transcription units has also been integrated. Twenty-eight cDNA fragments showed no similarity with known sequences, but 20 of these detected discrete mRNAs upon northern analysis. Their characterisation is still under investigation. Eleven new polymorphisms were also identified and localised, and the HFE genomic structure was better defined. This integrated transcription map considerably extends a recently published map of the HFE region. It will be useful for the identification of genetic defects mapping to this region and for providing template resources for genomic sequencing.
\end{abstract}

Keywords: haemochromatosis; HFE; transcription HAP; 6p22

\section{Introduction}

The generation of transcription maps of the human genome is an important step towards the identification

Correspondence: Paolo G asparini, M D, Servizio di G enetica Medica, IRCCS-O spedale 'CSS', I-71013 San Giovanni R otondo ( $\mathrm{Fg})$, I taly

R eceived 12 June 1997; revised 130 ctober 1997; accepted 22 O ctober 1997 of disease genes. D uring our project for the identification of the hereditary haemochromatosis $(\mathrm{HH})$ gene, we focused our attention on the short arm of chromosome 6 (6p22), in the region placed telomeric to marker D 6S105. R ecently, linkage disequilibrium and ancestral haplotype analysis carried out in a large series of patients, provided that the $\mathrm{HH}$ gene most likely resides in an interval located further telomeric than previously reported. ${ }^{1}$ 
This region was poorly investigated and characterised by a low representation of known transcripts. Thus, after cloning the entire $6 \mathrm{p} 22$ region in $\mathrm{YACs}^{2}$ we applied the CDNA selection technique to a $1 \mathrm{Mb}$ region covered by the YAC 790G 7, which spans most of the region defined by markers D6S1016 and D6S1921. A novel HLA class I-like gene (HFE), mutated in patients affected by $\mathrm{HH}$, has been isolated from this region, ${ }^{1}$ and its genomic structure and transcription orientation has been here reported. Location information using established and known markers and the new CDNA fragments was then integrated to achieve a refined map of the region, including a partial cosmid contig.

\section{Materials and Methods}

Isolation of YACs, cosmid clones, and STS mapping YAC clones were provided by the YAC screening centre (DIBIT-HSR, Milan). A II the clones with the exception of 935D 10 were previously reported in Malaspina et al. ${ }^{2}$ DNA was obtained following propagation of single colonies in A chilles heel cleavage $(\mathrm{A} \mathrm{HC})$ medium at $30^{\circ} \mathrm{C}$ for 48 hours. Total yeast DNA chromosomes were prepared in $100 \mu \mathrm{L}$ Seaplaque (FM C, R ockland, ME) agarose plugs.

A chromosome 6 specific cosmid library constructed at the L os A lamos $N$ ational L aboratory was kindly provided by the B aylor College of Medicine $\mathrm{H}$ uman $\mathrm{G}$ enome Center. $\mathrm{H}$ igh density filters (1536 clones/filter) were prepared for hybridisation screening by plating on to nylon filters from the thawed 384 microtiter dish stocks using the Biomek 2000 workstation. The membranes were transferred to appropriate agar plates for overnight growth, and processed for cell lysis and DNA fixation. ${ }^{3}$

A II publicly available and newly identified STS were used as probes to screen the arrayed chromosome 6 specific cosmid filters. In all, 287 cosmid clones were identified. They were retrieved, grown in individual wells of 96 well plates and transferred to filters as for the entire library. A II probes used in the hybridisation of either YACs or cosmids were preassociated with a $2 \times 10^{4}$ excess $(0.2 \mathrm{mg} / \mathrm{ml})$ of sonicated human placental DNA for 1 hour at $65^{\circ} \mathrm{C}$, in order to saturate repetitive DNA sequences. The hybridisation and washing conditions were as previously described. ${ }^{4}$

The following landmarks were integrated in the map:

- anonymous ST S: (D 6S1294);

- polymorphic markers: D6S2220, D6S2221, D6S2240, D 6S2238, D 6S2241, D 6S2236, D 6S2237, D6S1621, D6S2233, D6S1281. A II of them are available at the G enome D atabase (http://www-genome.wi.mit.edu).

- the IMAGE cD NA clone 307162 (clone zb51g06), used to determine the direction of transcription of $\mathrm{HFE}$ gene;

- 899G 1-1, A L U G 7, A LU G 12, 792G 12-3 are four anonymous probes obtained by A lu-PCR from YAC 899G 1, 790G 7 and 792G 12 using a mix 1:4 of A LUJ/ALUS primers $5^{5}$ and PCR conditions of: annealing $58^{\circ} \mathrm{C}$ for $1^{\prime}$, and extension $72^{\circ} \mathrm{C}$ for $2^{\prime}$ for 35 cycles. A liquots of the $P C R$ products or specific $A L U$ bands were isolated from low-melting agarose gel and used as probes.

\section{cDNA Selection and Characterisation}

Mammalian genomic DNAs were isolated from human leukocytes, from rodent cell lines and a mouse-human hybrid cell line GM 10629 obtained from NIGMS Human G enetic Mutant Cell Repository, Camden, New Jersey. Restriction digestions were carried out according to supplier's recommendations. Electrophoresis, blotting and hybridisation were carried out according to standard procedures. A fter hybridisation, the blots were washed (0.2X SSC with $0.1 \%$ SD S) at $60^{\circ} \mathrm{C}$ and exposed to autoradiography for $2-72 \mathrm{~h}$.

$R$ andomly primed $c D N A$ was prepared from poly- ${ }^{+} R$ NA of foetal liver, foetal brain, and placenta tissues and from total RNA of adult liver, and of the Caco-2 cell line (ATCC HTB 37). The artificial chromosome of Y A C $790 \mathrm{G} 7$ was transferred to nylon membrane ( $\mathrm{H}$ ybond $\mathrm{N}, \mathrm{A}$ mersham) and immobilised by U V-cross linking following separation by pulsed-field gel electrophoresis. Selection was carried out for two consecutive rounds of hybridisation to the immobilised artificial chromosome DNA. H ybridising CDNA was collected, amplified and cloned as described. .,7 $^{6}$

We picked and gridded 288 individual colonies on a microtiter format for ordering, prescreening and storage. Initial analysis of CDNA clones included a prescreening for ribosomal sequences. A pproximately $8 \%$ of the clones were eliminated as they hybridised with radiolabelled CDNA obtained from total R NA. A secondary screening for histone genes was carried out, and an additional $1 \%$ of clones was eliminated. Plasmids that did not hybridise in the prescreenings were isolated for further analysis. Of isolated inserts, $52 \%$ mapped to the starting Y A C clone. M embranes prepared from the gridded clones were also repeatedly hybridised with individual CDNA clones to eliminate overlapping or redundant clones. The sequence of both strands of the retrieved cDNAs was obtained with the dideoxy chain terminator method $^{8}$ using the Taq Dye Primer Cycle Sequencing $K$ it $(A B I)$ and the $373 A$ DNA Sequencer $(A B I)$. The resulting sequences were then analysed by comparison with BLA STXnon redundant protein, $B L A$ STN on G eneB ank, G eneB ank update, EMBL, EST, SW ISSprot databases.

Northern blotting was performed to determine the pattern of expression of each retrieved CDNA clone. Clontech H uman Northern B lots (Clontech, USA) containing several tissues (heart, brain, placenta, lung, liver, skeletal muscle, kidney, pancreas, spleen, thymus, prostate, testis, ovary, small intestine, colon, leukocytes) were used with the recommended conditions.

\section{Polymorphism Detection}

Oligonucleotides for PCR primers corresponding to the first 23 clones isolated (CD 30L, CD 36, CD 64, CD 77, CD 117, CD 140, CD 176, CD 218, CD 235, CD 282, CD 212, CD 123, CD 43, CD 88, CD 104, CD 105, CD 108, CD 110, CD 171, CD 203, CD 207, CD 240) were designed to run R NA-SSCP experiments for detecting nucleotide changes, as described. ${ }^{9,10}$ A nnealing temperatures for amplification and length of each PCR product are reported in (Table 3) (see R esults). PCR was performed on $500 \mathrm{ng}$ genomic DNA from 20 unrelated individuals according to standard protocols. A fter in vitro transcription with the incorporation of $(\alpha 32)$ rATP an aliquot of the reaction $(4.5 \mu \mathrm{l})$ was loaded on 
to a $6.5 \%$ nondenaturing polyacrylamide gel. Electrophoresis was performed at $30 \mathrm{~W}$ constant power for $13 \mathrm{~h}$. A fter electrophoresis, the gel was dried and subjected to autoradiography for $12 \mathrm{~h}$. Fragments with altered migration patterns were then sequenced as described above. When a polymorphism was detected, frequencies of alleles were assessed in a sample of 50 unrelated individuals.

\section{cDNA Library Screening}

CDNA -selection products, labelled with a-32P dCTP with M ultiprime K it (Beckman Instruments, Palo A Ito, CA) for a concentration of $1 \times 10^{6} \mathrm{cpm} / \mathrm{ml}$, were used to screen five human CD NA libraries: NT 2 neuronal precursor cell (937230 Stratagene, La Jolla, CA), duodenum (HL1156n Clontech Inc., Palo A Ito, CA ), liver (937224 Stratagene, L a Jolla, CA ), placenta (937225 Stratagene, L a Jolla, CA ) and foetal kidney (H L 3028b, Clontech Inc). Prehybridisation and hybridisation and washes were performed as previously described. ${ }^{2}$

\section{HFE Genomic Structure}

The HFE intron/exon boundaries have been defined using two strategies:

(1) generation of intron-containing genomic fragments by long-PCR using HFE CDNA-derived primers; and

(2) screening of a chromosome 6 specific cosmid library using PCR fragments corresponding to the HFE CDNA. ${ }^{1}$ $P C R$ was performed with a Perkin EImer Gene A mp 9600 thermal cycler, in reaction volumes of $25 \mu \mathrm{l}$ and DNA concentration of $250 \mathrm{ng} / \mathrm{ml}$. The reaction was continued for 30 cycles consisting of $1 \mathrm{~min}$ at $94^{\circ} \mathrm{C}, 1 \mathrm{~min}$ at $60^{\circ} \mathrm{C}$ and $2 \mathrm{~min}$ at $72^{\circ} \mathrm{C}$. The intron/exon boundaries of amplified fragments were sequenced in a 373A automatic sequencer (A pplied B iosystems) with the same PCR primers. Simultaneously, a chromosome 6 specific cosmid library, cloned in Lawrist 4 vector, was analysed by hybridisation with different CDNA fragments generated by PCR. Six positive clones (23B 12, $11 \mathrm{~A} 9,31 \mathrm{H} 6,45 \mathrm{E} 12,24 \mathrm{~A} 11,39 \mathrm{~K} 16)$ were isolated and analysed by PCR with CDNA primer pairs (Table 2, see R esults). Five clones (23B 12, 11A 9, 45E 12, 24A 11, 39K 16) were positive for all six exons of HFE gene plus the $3^{\prime}$ UTR, while clone $31 \mathrm{H} 6$ did not contain the $3^{\prime}$ UTR. A primer designed on the first exon of HFE gene was used to sequence the $5^{\prime} U T R$ region.

\section{Results}

We investigated the interval on $6 \mathrm{p} 22$ defined centromerically by the markers D 6S1016 and D 6S1921. We had previously established an extended comprehensive physical map revealing that the YAC clone 79067 essentially spanned the defined internal and thus it was chosen for CDNA selection experiments. In the meantime, another group reported the isolation of a gene, named $\mathrm{HFE}$; from this interval that is mutated in haemochromatosis patients. ${ }^{1}$ In addition, they described several new polymorphisms within this region. We incorporated these new polymorphisms and were able to establish the orientation and position of the HFE gene with our map.

\section{cDNA Selection Results}

Thirty-seven unique CDNA selection products were selected, sequenced, and verified to map to $Y A C$ clones 790G 7, 792G 12, 935D 10,764H 9, 905G 1, 899G 1, and 767G 12. To confirm assignment to chromosome 6 , each CDNA was hybridised to total human DNA and to a mouse hybrid cell line that contains chromosome 6 as its only human material. Sequence analysis of each clone by alignment to the public databases revealed that 28 corresponded to a new sequence, while the remaining nine shared overlapping sequence or were similar to previously known genes. A complete summary of the results obtained is reported in Table 1.

\section{cDNAs of Known Human Genes}

$\mathrm{N}$ ine clones shared overlapping sequence, and/or were homologous to known genes, as summarised in Table 1. O ne clone, CD 33, was identical to a sodium-phosphate pump (NPT 1) ${ }^{11}$ and had already been assigned to the 6p23-6p21.3 region. This transcription unit was mapped within the end of YAC $928 \mathrm{C} 4$ and was indeed negative on the cosmids of the region. Clone CD 235 was identical to a gene encoding a RING finger protein (Y 07829). A nother clone, CD 75, showed similarity with the bovine butyrophilin (BTN) and it was not further investigated. Six additional clones (CD 23, CD 58, CD 134, CD 216, CD 231, CD 296) shared overlapping sequences with known repetitive elements, including LINE 1, and mer sequences (Table 1).

To attempt to get full length CDNAs, groups of retrieved fragments were then used to screen five different human CDNA libraries. Twelve different CDNA clones were isolated and mapped on to the YAC and cosmid clones (data not shown). In particular, two CDNA clones ( $h D$ uoll and hDuo18) were positive with $\mathrm{CD} 30 \mathrm{H}$, three (hNT2 6, hNT2 7b, hNT2 14) were positive with CD 115, five (hKi2, hKila, hKi5b, hK i9, hKi11) were positive with CD 274, one (hLi12) was positive with CD 123. Work is in progress to characterise these CDNA s further and to get more clones for the remaining $C D N A$ selection products using additional CDNA libraries.

\section{RNA Hybridisation}

CDNA clones isolated by CDNA selection were tested by hybridisation to polyA ${ }^{+} \mathrm{R} N \mathrm{~A}$ of a series of tissues. The results are presented in Table 2 . Fifteen clones revealed a wide distribution of tissue expression, while five demonstrated more specific expression patterns. CD 190 was expressed in only prostate (Figure 1). CD 212 and CD 235 gave discrete mR NA s only in liver 
(Figure 1). Two other clones were expressed in limited sets of tissues, CD 274 in liver and kidney, and CD 123 in liver, muscle, kidney and pancreas. A Il these 20 clones detectedone single band either on chromosome 6 or genomic DNA (data not shown). Five clones (CD 36, CD 105, CD 117, CD 203, and CD 218) detected less discrete signals on northern blots, indicating either hybridisation to a series of mRNAs or non-specific hybridisation. In this case, all clones detected one band on chromosome 6 DNA, while at genomic level clones CD 117 and CD 203 detected additional bands (data not shown). For the remaining clones (CD 77, CD 140, CD 152, CD 207) expression levels appeared below the sensitivity of our northern assay. Gene fragments CD 43, CD 115, and CD 219, showed identical expression patterns. A s they are located in close proximity to each other, they are likely to correspond to a single transcription unit or gene. Four additional transcription units arise from four pairs of closely positioned clones, CD 110/CD 282, CD 88/CD 30L, CD 240/CD 30H, and CD 176/CD 254. They also showed consistent mR NA sizes and patterns of expression, while RT-PCR , leading to one amplified product, confirmed the presence of only one transcript for each transcription unit (data not shown). Clones CD 110/CD 282 (transcription unit 4) define a sequence with an homology of $88 \%$ at protein level with NPT 3 gene (NPT3h. In contrast, the expression pattern and sequence homologies for CD 183, CD 123, and CD 171 clones, that all reside on the same $51 \mathrm{M} 1$ cosmid, are consistent with a minimum of three

Table 1 Summary of selected cD NA clones. The first 31 gene fragments correspond to new sequences while the remainder shared overlapping sequence, and/or were homologous to previously known genes

\begin{tabular}{|c|c|c|c|}
\hline Clone & Size (bp) & R emarks & E M BL Acc. No. \\
\hline $\begin{array}{ll}\text { CD } 20 \\
\text { CD } 30 H \\
\text { CD } 30 L \\
\text { CD } 36 \\
\text { CD } 43 \\
\text { CD } 64 \\
\text { CD } 675 \\
\text { CD } 77 \\
\text { CD } 88 \\
\text { CD } 105 \\
\text { CD } 110 \\
\text { CD } 115 \\
\text { CD } 117 \\
\text { CD } 123 \\
\text { CD } 140 \\
\text { CD } 152 \\
\text { CD } 171 \\
\text { CD } 176 \\
\text { CD } 190 \\
\text { CD } 203 \\
\text { CD } 207 \\
\text { CD } 212 \\
\text { CD } 218 \\
\text { CD } 219 \\
\text { CD } 240 \\
\text { CD } 254 \\
\text { CD } 274 \\
\text { CD } 282\end{array}$ & $\begin{array}{r}578 \\
514 \\
362 \\
655 \\
1100 \\
637 \\
317 \\
549 \\
651 \\
635 \\
697 \\
446 \\
689 \\
800 \\
496 \\
1100 \\
514 \\
1000 \\
1000 \\
480 \\
560 \\
529 \\
1100 \\
442 \\
800 \\
407 \\
570 \\
615\end{array}$ & $\begin{array}{l}\text { N ew sequence } \\
N \text { ew sequence } \\
N \text { ew sequence } \\
N \text { ew sequence } \\
N \text { ew sequence } \\
N \text { ew sequence } \\
N \text { ew sequence } \\
N \text { ew sequence } \\
N \text { ew sequence } \\
N \text { ew sequence } \\
N \text { ew sequence } \\
N \text { ew sequence } \\
N \text { ew sequence } \\
N \text { ew sequence } \\
N \text { ew sequence } \\
N \text { ew sequence } \\
N \text { ew sequence } \\
N \text { ew sequence } \\
N \text { ew sequence } \\
N \text { ew sequence } \\
N \text { ew sequence } \\
N \text { ew sequence } \\
N \text { ew sequence } \\
N \text { ew sequence } \\
N \text { ew sequence } \\
N \text { ew sequence } \\
N \text { ew sequence } \\
N \text { ew sequence }\end{array}$ & 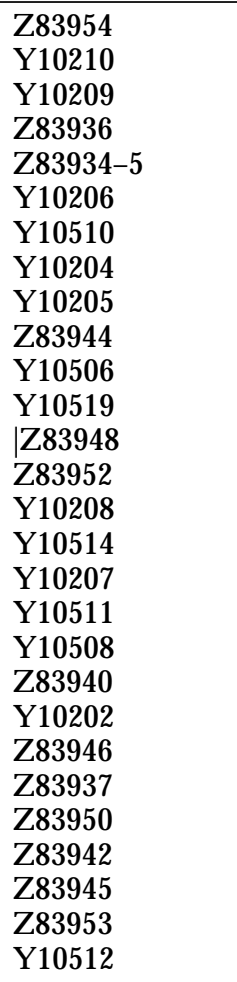 \\
\hline $\begin{array}{l}\text { CD } 33 \\
\text { CD } 134 \\
\text { CD } 235\end{array}$ & $\begin{array}{l}503 \\
436 \\
514\end{array}$ & $\begin{array}{l}\text { Identical to H. Sap. mR NA for } \mathrm{Na}^{+}-\text {ph } \\
\text { I dentical to a human line } 1 \text { repetitive element } \\
\text { I dentical to H. Sap. gene encoding R ING finger protein }\end{array}$ & \\
\hline $\begin{array}{l}\text { CD } 23 \\
\text { CD } 58 \\
\text { CD } 75 \\
\text { CD } 216 \\
\text { CD } 231 \\
\text { CD } 296\end{array}$ & $\begin{array}{l}403 \\
900 \\
589 \\
672 \\
613 \\
320\end{array}$ & $\begin{array}{l}\text { Similar to human } K \text { pnl repetitive sequence } \\
\text { Similar to mer } 10 \text { repetitive element } \\
\text { Similar to bovine butyrophilin mR NA } \\
\text { Similar to human } L 1 \text { repetitive element } \\
\text { Similar to human } L 1 \text { repetitive element } \\
\text { Similar to repetitive elements }\end{array}$ & $\begin{array}{l}Z 83955 \\
\text { Y } 10515-6 \\
\text { Y } 10203 \\
\text { Y } 10509 \\
\text { Z } 83951 \\
\text { Z } 83949\end{array}$ \\
\hline
\end{tabular}


different transcription units. Combining the data from the physical map with expression results, a minimum of 14 transcription units, in addition to already known genes of the region, were identified (Figure 2).

\section{Identification of New Polymorphisms}

The RNA -SSCP technology allowed us to detect 11 new polymorphisms (clones CD 30L, CD 36, CD 64, CD 77, CD 117, CD 140, CD 176, CD 212, CD 218, CD 235, $C D 282)$ as shown in Table 3. Details on the allele frequencies of each polymorphism are also reported. In each case, $M$ endelian inheritance was confirmed in 20 large kindreds.

Table 2 R NA analysis of the gene fragments corresponding to new sequences

\begin{tabular}{|c|c|c|c|}
\hline Clones & Size (K b) & $\begin{array}{l}\text { Widely } \\
\text { expressed }\end{array}$ & $\begin{array}{l}\text { Specific } \\
\text { issue }\end{array}$ \\
\hline $\begin{array}{ll}C D & 20 \\
C D & 30 \mathrm{~L} \\
\text { CD } & 30 \mathrm{H} \\
\text { CD } & 43 \\
\text { CD } & 64 \\
\text { CD } & 67 \mathrm{~S} \\
\text { CD } & 88 \\
\text { CD } & 110 \\
\text { CD } & 115 \\
\text { CD } & 123\end{array}$ & $\begin{array}{l}2 \\
5 \\
6.5 \\
5.5 \\
4.5 \\
2 \\
5 \\
5 \\
5.5 \\
2.8\end{array}$ & $\begin{array}{l}+ \\
+ \\
+ \\
+ \\
+ \\
+ \\
+ \\
+ \\
+ \\
-\end{array}$ & $\begin{array}{l}- \\
- \\
- \\
- \\
- \\
- \\
- \\
- \\
- \\
\text { liv., musc., kidn., panc. }\end{array}$ \\
\hline $\begin{array}{ll}\text { CD } & 171 \\
\text { CD } & 176 \\
\text { CD } & 190 \\
\text { CD } & 212 \\
\text { CD } & 219 \\
\text { CD } & 235 \\
\text { CD } & 240 \\
\text { CD } & 254 \\
\text { CD } & 274 \\
\text { CD } & 282\end{array}$ & $\begin{array}{l}1.8 \\
2 \\
3 \\
5.5 \\
5.5 \\
4 \\
6.5 \\
2 \\
2 / 4 \\
5\end{array}$ & $\begin{array}{l}+ \\
+ \\
- \\
- \\
+ \\
- \\
+ \\
+ \\
- \\
+\end{array}$ & $\begin{array}{l}- \\
\text { - } \\
\text { prostate } \\
\text { liver } \\
\text { - } \\
\text { liver } \\
- \\
\text { - } \\
\text { liver, kidney }\end{array}$ \\
\hline $\begin{array}{ll}\text { CD } & 36 \\
\text { CD } & 105 \\
\text { CD } & 117 \\
\text { CD } & 203 \\
\text { CD } & 218 \\
\text { CD } 77 \\
\text { CD } 140 \\
\text { CD } 152 \\
\text { CD } 207\end{array}$ & $\begin{array}{l}\text { smear } \\
\text { smear } \\
\text { smear } \\
\text { smear } \\
\text { smear } \\
\text { ND } \\
\text { ND } \\
\text { ND } \\
\text { ND }\end{array}$ & & \\
\hline
\end{tabular}

mR NA sizes detected in 16 tissues (heart, brain, placenta, lung, liver, skeletal muscle, kidney, pancreas, spleen, thymus, prostate, testis, ovary, small intestine, colon, leukocytes) are indicated. Fragments displaying only limited expression patterns are indicated. Five CD NA clones (CD 36, CD 109, CD 117, CD 203, CD 218) detected less discrete signals on the blots, indicating a series of RNAs or non-specific hybridisation, whilst for four clones (CD 77, CD 140, CD 152, $C D 207)$ expression levels were below the sensitivity of the assay. ND : as data.

\section{Isolation of Cosmid Clones}

A II the available fragments together with Alu-PCR probes derived from the YAC clones were used to screen a chromosome 6 specific cosmid library to detect a total of 287 cosmid clones. The cosmid clones allowed for the ordering and precise mapping of the different STSs. The compiled results of these experiments are shown in Figure 2.

\section{Genomic Structure and Orientation of HFE gene}

The human HFE gene spans approximately $9.5 \mathrm{~Kb}$ and the open reading frame (ORF) is contained in 6 exons. $A n$ additional non-coding exon is located within the $3^{\prime}$ UTR. The size of the 7 introns ranges from $160 \mathrm{bp}$ (intron 4) to approximately $3 \mathrm{~K} \mathrm{~b}$ (intron 1 ). A II exon/ intron splice junctions conform to the eukaryotic $5^{\prime}$ donor $3^{\prime}$ acceptor consensus splice junctions GT/A G rule (Table 4). Junctions at all introns are type 1 (splicing occurring after the first based of the codon). Two cosmid clones (23B 12 and $31 \mathrm{H} 6$ ) were further analysed to characterise the upstream promoter region. A mong the $448 \mathrm{bp}$ of the putative regulatory regions, we noted a region relatively $G C$ rich $(64 \%$ from base 1 to -78 ) and the absence of classical TA TA and CA AT boxes. Thus, the human HFE promoter has structural features in common with those of several housekeeping genes and is consistent with the ubiquitous expression pattern of the mRNA in all tested human tissues. ${ }^{1}$ A part from the noted increase in GC content, 80-90 bp before the initiation codon, no significant homology of the putative regulatory sequence of the HFE gene has been found to promoter regions of other HLA class I genes. A more precise characterisation of the promoter by functional analysis with a reporter gene, and identification of the trans-acting factors will provide insights into the control of expression of the HFE gene.

$\mathrm{U}$ sing primers designed from genomic sequence established by analysis of HFE genomic structure, two probes were generated corresponding to the $5^{\prime}$ end of the HFE gene, and to the middle part of the gene, together with the EST 307162 which corresponds to the $3^{\prime}$ end of the HFE gene. The three probes were used in hybridisation experiments on YAC and cosmid filters. The presence or absence of the three probes on cosmid clones mapped in the region and the simultaneous presence of the $3^{\prime}$ end of the gene and marker D 6S2238, that has been mapped centromerically to $\mathrm{HFE}^{1}{ }^{1}$ on cosmid $39 \mathrm{~K} 16$ allows us to determine that HFE is transcribed from telomere to centromere. Furthermore 
our results showed that most of the $\mathrm{HFE}$ gene is contained in a portion of Y A C 790G 7 which is deleted in our clone.

\section{Discussion}

The generation of transcription maps is an important step towards the definition of the human genome and the identification of functioning genes. We focused our attention on a $1 \mathrm{MB}$ region of $6 \mathrm{p} 22$, where the $\mathrm{HH}$ locus was positioned. Using a large YAC from our previously assembled contig, ${ }^{2}$ cDNA selection experiments were carried out.

Thirty-seven gene segments have been isolated; 28 of them corresponded to new sequences, while the remaining nine shared overlapping sequence or were similar to previously known genes. The isolated cD NA s together with established or published STSs and markers provided sufficient landmark density to cover approximately $90 \%$ of the $1 \mathrm{Mb}$ interval with cosmid clones. mR NA s sizes and expression patterns were used to establish the number of transcription units identified by the 37 cD NA fragments analysed. In most cases, for the fragments that map close together different expression patterns or different RNA sizes were detected. Combining the data from the physical map with expression results, at least 14 transcription units in total were detected in addition to known genes of the region such as HFE, NPT 1, BTN etc.

The absence of integration between either a detailed genetic or a medium-range physical map of the region does not allow comparisons for more precise locations of the transcription units identified. Our data clearly suggests the presence of a high gene density in this region of $6 \mathrm{p} 22$ with an average gene frequency of a gene approximately every $80 \mathrm{~Kb}$. Our data are in agreement with those recently reported in a $1 \mathrm{Mb}$ transcription map of the HFE region, that describes 20 novel transcripts. ${ }^{12}$ This latter map extends more centromerically, but a minimum overlap of approximately $300 \mathrm{~K} \mathrm{~b}$ with our map occurs in the area of the

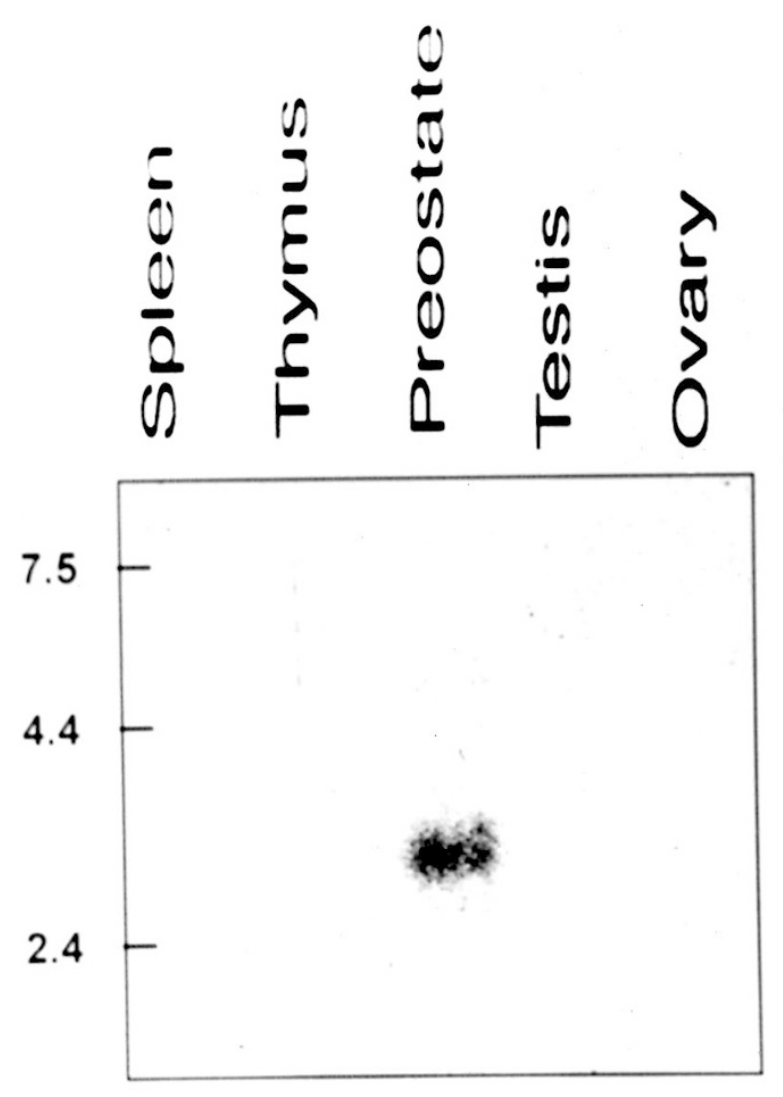

CD 190
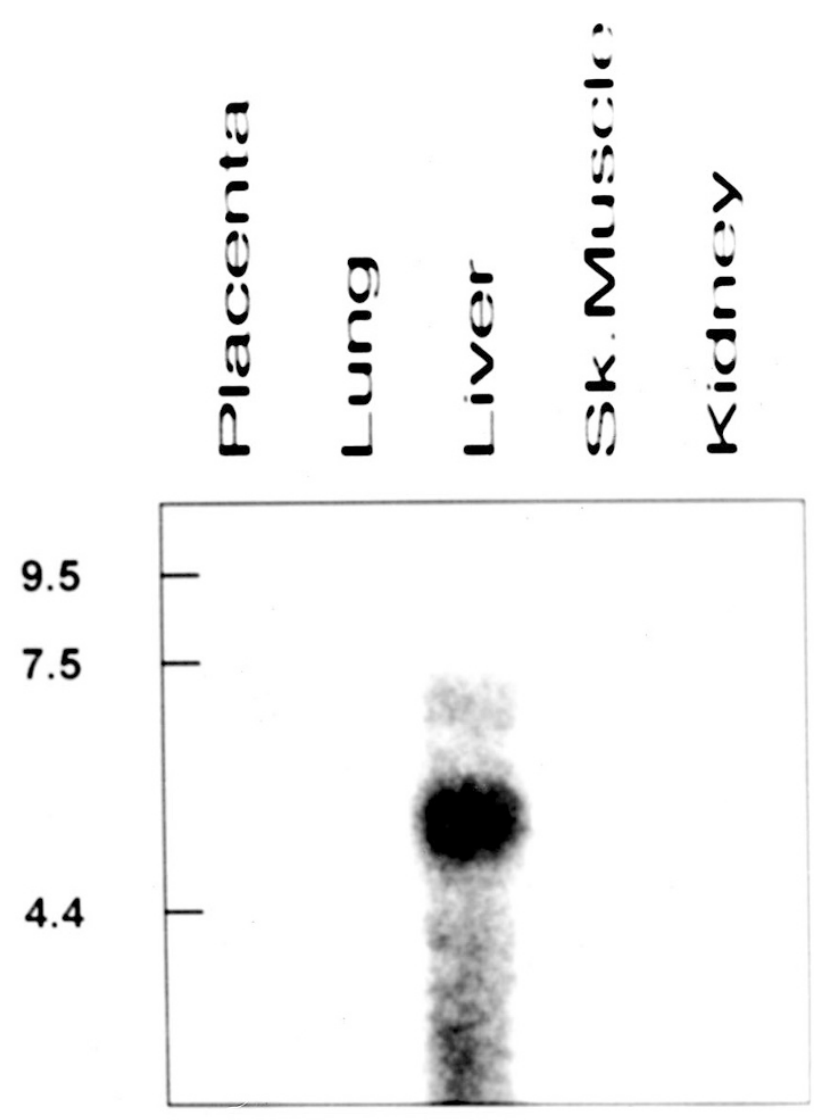

CD 212

Figure 1 Northern results of clones CD 190 and CD 212 that show specific tissue expression in prostate and in liver respectively 
cen

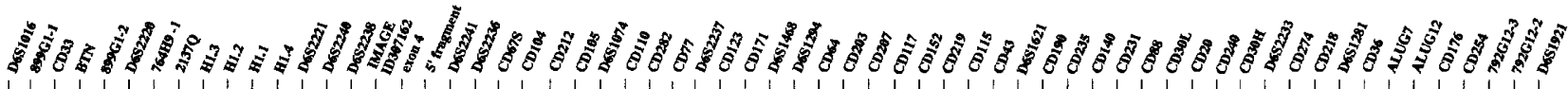

YAC

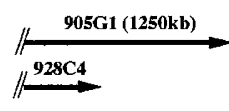

$764 \mathrm{H} 9(1160 \mathrm{~kb})$

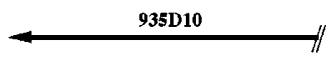

$790 \mathrm{G} 7(1040 \mathrm{~kb})$

$899 \mathrm{G1}(850 \mathrm{~kb})$

767G12 (1740kb)

cosmids

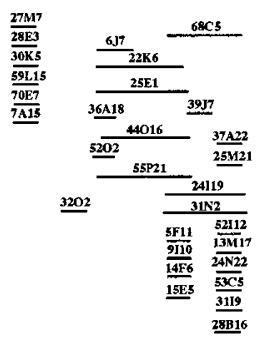

$\frac{\frac{\frac{45 E 12}{11 \mathrm{~A} 9}}{23812}}{\frac{31 \mathrm{~B} 6}{2 \mathrm{AA11}}}$

$\frac{70622}{8 \mathrm{M} 16}^{\frac{12 \mathrm{BB} 6}{6 \mathrm{65 \textrm {L } 2 4}}}$

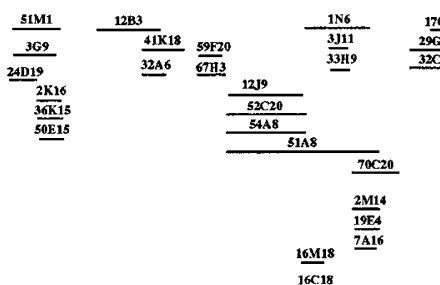

\section{$792 \mathrm{G12}(610 \mathrm{~kb})$}

transcription

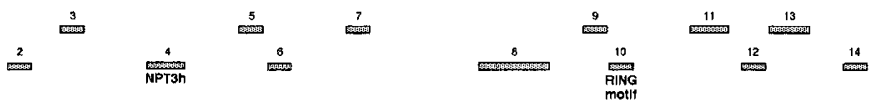

Figure 2 The transcription/physical map of the HFE gene region. The isolated CDNA s and the class I genes were positioned by bins on cosmids. The relative position of each gene fragment within a given cosmid is not known

Table 3 D escription of the polymorphisms identified by 12 gene fragments

\begin{tabular}{|c|c|c|c|c|c|c|}
\hline Clones & Polymorphisms & O ligonucleotide sequences & $\begin{array}{l}\text { A nnealing } \\
\text { temp. }\left({ }^{\circ} \mathrm{C}\right)\end{array}$ & $\begin{array}{l}\text { A mplification } \\
\text { product size (bp) }\end{array}$ & $\begin{array}{l}\text { Frequency } \\
\text { Allele } 1\end{array}$ & Allele 2 \\
\hline CD 30L & M ae III & $\begin{array}{l}\text { F-TCTA A G GA A TCA G CCCGCC } \\
\text { R-TGCTGAAATTGGAAAGGTGA }\end{array}$ & 60 & 376 & $75 \%$ & $15 \%$ \\
\hline CD 36 & NlallI & $\begin{array}{l}\text { F-GACA GCACA A ATGTTGA A GT } \\
\text { R-CCACTTCAGAGAGAGTAACA }\end{array}$ & 60 & 327 & $67 \%$ & $33 \%$ \\
\hline CD 64 & D de I & $\begin{array}{l}\text { F-GATTCA G GA A ATTCTCTA A } \\
\text { R-TCTGACA GTTGTGAAAGGAC }\end{array}$ & 60 & 185 & $65 \%$ & $35 \%$ \\
\hline CD 77 & Rna-SSCP & $\begin{array}{l}\text { F-G A ATGGACA G CATGGTTTC } \\
\text { R-ATCCATA GTTTG TCTTCCTT }\end{array}$ & 58 & 415 & $82 \%$ & $18 \%$ \\
\hline CD 117 & R na-SSCP & $\begin{array}{l}\text { F-CACA A CTG TCCA A CA G A ATC } \\
\text { R-TGA G G CTATA GATGA G G ATG }\end{array}$ & 58 & 696 & $89 \%$ & $11 \%$ \\
\hline CD 140 & R na-SSCP & $\begin{array}{l}\text { F-A GCG TA CA CTCTTGA G G G A T } \\
\text { R-GCTTCA G GTTA CCTCA GC }\end{array}$ & 58 & 448 & $77 \%$ & $23 \%$ \\
\hline CD 176 & Rna-SSCP & $\begin{array}{l}\text { F-GCA GA GCA GCA A CA ACT } \\
\text { R-ACA GTTA GACATTGA A GCT }\end{array}$ & 58 & 265 & $93 \%$ & $7 \%$ \\
\hline CD 212 & R na-SSCP & 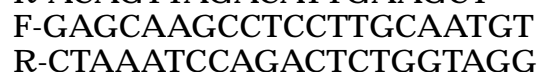 & 54 & 383 & $84 \%$ & $16 \%$ \\
\hline CD 218 & $\mathrm{~N}$ si I & $\begin{array}{l}\text { F-CA G CACA G TG TACCTCATA G } \\
\text { R-CCA ACA ACTGGTACA A ATG C }\end{array}$ & 55 & 266 & $86 \%$ & $14 \%$ \\
\hline CD 235 & D de I & $\begin{array}{l}\text { F-ATTA TA G CA CA G TG T G G TG G } \\
\text { R-ATG G CA CA CATCTG CCCCTA A }\end{array}$ & 60 & 266 & $73 \%$ & $27 \%$ \\
\hline CD 282 & R na-SSCP & $\begin{array}{l}\text { F-CTACA ATGCTGAGTTGCACA G } \\
\text { R-ATTTG G GCA A ATGG GCT }\end{array}$ & 58 & 467 & $71 \%$ & $29 \%$ \\
\hline
\end{tabular}


histone genes. Transcription units 1 (NPT 1), and BTN (butyrophilin gene) are contained in both maps. For the sodium-phosphate transporter NPT1 gene, recently described, ${ }^{11}$ we detected two hybridisation signals, one very strong in the area reported in Figure 1 and one somewhat weaker in the region defined by Ruddy et al. ${ }^{12}$ In addition, another sodium-phosphate pump gene, highly homogolous to NPT 3 gene and thus named NPT 3h, was isolated and placed telomeric to NPT 3 and to marker D 652236 of the R uddy map. Combining the data from the two maps, it is possible to suggest that this region arose from several duplications of genes such as butyrophilin, histone, HLA class I, NPT and RING finger protein, yielding a high gene density.

During the construction of our map, the HFE gene was isolated from this interval. ${ }^{1} \mathrm{~B}$ y defining its genomic structure and integration with the map the transcriptional orientation of the HFE gene from telomere to centromere was clearly determined. The HFE genomic structure will facilitate the search for mutations from genomic DNA in all patients. A consistent proportion of our $\mathrm{HH}$ chromosomes of Southern Europe are negative for the presence of the $\mathrm{C} 282 \mathrm{Y}$ mutation. ${ }^{13,14}$ The possibility of an extensive analysis of the HFE gene at D NA level will help to define the exact proportion of $\mathrm{HH}$ patients carrying a mutated allele, and further support or exclude the possibility of genetic heterogeneity.
Finally, the new polymorphisms here described could be useful for linkage analysis and for the construction of at-risk $\mathrm{HH}$ haplotypes.

In conclusion, we describe the isolation and mapping of several new gene fragments on 6p22. Our map extends the recently published map increasing the number of transcripts in the area of the HFE gene. A dditional genes, both known and novel, could be isolated either by increasing the number of unique clones characterised in detail, or by additional cD NA selection experiments with cDNA s from tissues not used in the present study. The novel fragments have already been useful as single-copy probes for screening larger-insert cD NA libraries, in order to complete their respective gene characterisation and for refining the physical map. This material forms a useful source for completion of the full transcript map of $6 p 22$, for the future identification of defects and genes located to this region, and for developing template resources for genomic sequencing.

\section{Acknowledgements}

The first two named authors of this paper contributed equally to this work. JM Rommens is a scholar of the M edical R esearch Council of Canada, and BIOMED. This work was supported by grants from the Italian Ministry of $\mathrm{H}$ ealth, AIRC (A ssociazione Italiana Ricerca Cancro), Telethon (G rant E 149 and E 537).

Table 4 B rief description of HFE intro-exon boundaries and primers useful for amplifying at genomic level

\begin{tabular}{|c|c|c|c|c|}
\hline Exon & Positiona & $\begin{array}{l}\text { Donor } \\
\text { sequence }\end{array}$ & $\begin{array}{l}\text { A cceptor } \\
\text { sequence }\end{array}$ & $\begin{array}{l}\text { Primers } \\
\left(5^{\prime} \text { to } 3^{\prime}\right)\end{array}$ \\
\hline$\overline{1}$ & $1-297$ & & GCT G C gtgagt & $\begin{array}{l}\text { F-TTCA CA A G CA G G TA CCTTCT } \\
\text { R-ggtcctccaaagttagcaaac }\end{array}$ \\
\hline 2 & $298-561$ & ctccagG TTCA & CA A G G gtatgt & $\begin{array}{l}\mathrm{F} \text {-acatggttaaggcctgttgc } \\
\mathrm{R} \text {-agctgtttccttcaagatgc }\end{array}$ \\
\hline 3 & $562-837$ & ttccagA G TCC & A CA A G gtatgg & $\begin{array}{l}\text { F-aatagggacctattcctttgg } \\
\text { R -gtagaaaagctctgacaacct }\end{array}$ \\
\hline 4 & 838-1113 & gtcaagTG CCT & CT G G G gtatgt & $\begin{array}{l}\text { F-tggcaagggtaaacagatcc } \\
\text { R-ctcaggcactcctctcaacc }\end{array}$ \\
\hline 5 & $1114-1227$ & ttttagA G C C C & TTCA A gtgagt & $\begin{array}{l}\mathrm{F} \text {-gtatgtgactgatgagagcca } \\
\mathrm{R} \text {-cagaggtactaagagacttc }\end{array}$ \\
\hline 6 & $1228-2304$ & ccacagG A G G A & A GCGG gtggat & $\begin{array}{l}\text { F-tagtgcccaggtctaaattg } \\
\text { R-gttagccaggatggtctcga }\end{array}$ \\
\hline 7 & $2305-2746$ & ccaaagT G CTG & & $\begin{array}{l}\text { F-accatgttggccaggctgg } \\
\text { R-CA ATA CA ATGTA CA TTAT }\end{array}$ \\
\hline
\end{tabular}

EMBL accessior numbers for the entire genomic structure are: Y 09801 (promoter and exon 1), Y 09800 (exon 2 and 3), $Y 09803$ (exon 4 and 5), Y 09799 (exon 6), Y 09802 (exon 7).

aE xon sequences are in capital letters; intron sequences are in lower case letters; exon positions are in coding sequence; 


\section{References}

1 Feder J N et al: A novel M HC class I-like gene is mutated in patients with hereditary haemochromatosis. Nature G enetics 1996; 13: 399-408.

2 Malaspina $P$ et al: Construction of a YAC contig covering human chromosome 6p22. G enomics 1996; 36: 399-407.

3 Franco B et al: A gene deleted in Kallmann's syndrome shares homology with neural cell adhesion and axonal path-finding molecules. Nature 1991; 353: 529-536.

4 Wapenaar MC et al: A YAC based binning strategy facilitating assembly of cosmid contig: 1.6 megabases of overlapping cosmid in Xp22. Hum Mol Genet 1994; 3: 1155-1161.

5 Ferrero $G B$ et al: A $n$ integrated physical and genetic map of a $35 \mathrm{M} \mathrm{b}$ region on chromosome X p22.3-X p21.3. H um M ol G enet 1995; 10: 1821-1827.

6 Rommens J et al: A transcription map of the region containing the $\mathrm{H}$ untington disease gene. $\mathrm{H}$ um $\mathrm{M}$ ol $\mathrm{G}$ enet 1993; 2: 901-907.

7 Rommens J et al: Towards a transcriptional map of the q21-q22 region of chromosome 7. In: H ochgeshwender W, Gardiner K (eds). I dentification of Transcribed Sequences. Plenum Press: New York, 1994, pp65-79.
8 Sanger F, Nicklen S, Coulson A : DNA sequencing with chain terminating inhibitors. Proc Natl Acad Sci USA 1977; 74: 5463-5467.

9 Sarkar G, Y oon H-S, Sommer S: Screening for mutations by RNA single-strand conformation polymorphisms (rSSCP): comparison with D NA -SSC P.. Nucleic A cids Res 1992; 20: 871-878.

10 Bisceglia L, G rifa A, Zelante L, Gasparini P: Development of RNA SSCP protocols for the identification and screening of CFTR mutations: identification of two new mutations. H um M ut 1994; 4: 136-140.

11 Chong SS, Kristjansson K, Zoghby HY, Hughes MR: Molecular cloning of the CDNA encoding a human renal sodium phosphate transport protein and its assignment to chromosome 6p21.3-p23. Genomics 1993; 18: 355-359.

12 Ruddy DA et al: A 1.1 transcript map of the hereditary hemochromatosis locus. G en R esearch 1997; 7: 441-456.

13 Borot $\mathrm{N}$ et al: M utation in the M H C class I-like candidate gene for hemochromatosis in French patients. I mmunogenetics 1997; 45: 320-324.

14 Carella M et al: M utation analysis of HFE gene in I talian hemocromatosis patients. A mer J Hum Gen 1997; 60: 828-832. 